OPEN ACCESS

Edited by:

Shiwei Xie,

Guangdong Ocean University, China

Reviewed by:

Xiaofang Liang,

Chinese Academy of Agricultural

Sciences (CAAS), China

Mansour Torfi Mozanzadeh,

South Iran Aquaculture Research

Center, Iran

Nan Bai,

Shandong University, China

${ }^{*}$ Correspondence:

Dong Han

hand21cn@ihb.ac.cn

Specialty section:

This article was submitted to

Aquatic Physiology,

a section of the journal

Frontiers in Physiology

Received: 26 August 2021 Accepted: 25 November 2021

Published: 21 December 2021

Citation:

LiU Y, LU Q, Xi L, Gong Y, SU J, Han D, Zhang Z, Liu H, Jin J, Yang Y,

Zhu $X$ and Xie S (2021) Effects of Replacement of Dietary Fishmeal by Cottonseed Protein Concentrate on Growth Performance, Liver Health, and Intestinal Histology of Largemouth Bass (Micropterus salmoides)

Front. Physiol. 12:764987. doi: 10.3389/fphys.2021.764987

\section{Effects of Replacement of Dietary Fishmeal by Cottonseed Protein Concentrate on Growth Performance, Liver Health, and Intestinal Histology of Largemouth Bass (Micropterus salmoides)}

\author{
Yulong Liu1,2, Qisheng Lu1,2, Longwei Xi1,2, Yulong Gong1,2, Jingzhi Su1,2, Dong Han 1,2,3*, \\ Zhimin Zhang ${ }^{1}$, Haokun Liu' ${ }^{1}$, Junyan Jin' ${ }^{1}$, Yunxia Yang ${ }^{1}$, Xiaoming Zhu ${ }^{1}$ and \\ Shouqi Xie ${ }^{1,2,4}$
}

${ }^{1}$ State Key Laboratory of Freshwater Ecology and Biotechnology, Institute of Hydrobiology, Chinese Academy of Sciences, Wuhan, China, ${ }^{2}$ College of Advanced Agricultural Sciences, University of Chinese Academy of Sciences, Beijing, China, ${ }^{3}$ Hubei Engineering Research Center for Aquatic Animal Nutrition and Feed, Wuhan, China, ${ }^{4}$ The Innovative Academy of Seed Design, Chinese Academy of Sciences, Wuhan, China

An 8-week feeding trial was conducted to explore the effects of replacement of dietary fishmeal by cottonseed protein concentrate (CPC) on growth performance, liver health, and intestine histology of largemouth bass. Four isoproteic and isolipidic diets were formulated to include $0,111,222$, and $333 \mathrm{~g} / \mathrm{kg}$ of CPC, corresponding to replace $0 \%$ (D1), 25\% (D2), 50\% (D3), and 75\% (D4) of fishmeal. Two hundred and forty largemouth bass $(15.11 \pm 0.02 \mathrm{~g})$ were randomly divided into four groups with three replicates per group. During the experiment, fish were fed to apparent satiation twice daily. Results indicated that CPC could replace up to 50\% fishmeal in a diet for largemouth bass without significant adverse effects on growth performance. However, weight gain rate (WGR), specific growth rate (SGR), feed efficiency (FE), and condition factor (K) of the largemouth bass were significantly decreased when $75 \%$ of dietary fishmeal that was replaced by CPC. The whole body lipid content was increased with the increasing of dietary CPC levels. Oil red O staining results indicated that fish fed the D4 diet showed an aggravated fat deposition in the liver. Hepatocytes exhibited serious degeneration, volume shrinkage, and inflammatory cells infiltration in the D4 group. Intestinal villi appeared shorter and sparse with severe epithelial damage in the D4 group. The transcription levels of anti-inflammatory cytokines, such as transforming growth factor $\beta$ (tgf- $\beta$ ), interleukin 10 (il-10), and interleukin $11 \beta$ (il-11 $\beta$ ), were downregulated in the D4 group. The lipid metabolism-related genes carnitine palmitoyl transferase 1 (cpt1), peroxisome proliferator-activated receptor $\alpha$ (ppar $\alpha$ ), and target of rapamycin (TOR) pathway were also significantly downregulated in the D4 group. It was concluded that 
suitable replacement of fishmeal by less than $222 \mathrm{~g} \mathrm{CPC} / \mathrm{kg}$ diet had a positive effect on growth performance of fish, but an excessive substitution of $75 \%$ fishmeal by CPC would lead to the suppressed growth, liver inflammation, and intestinal damage of largemouth bass.

Keywords: cottonseed protein concentrate, growth, inflammation, intestinal histology, TOR pathway

\section{INTRODUCTION}

Fishmeal is known as the preferential protein ingredient in aquafeeds due to its high digestible protein content, balanced amino acid profile, and fewer anti-nutritional factors (NRC, 2011). However, the rapid development of aquaculture and aquafeeds increases the imbalance between supply and demand of fishmeal because of the unsustainable fisheries resources and the increasing price of fishmeal (Naylor et al., 2009; Turchini et al., 2018). Therefore, finding new alternative and efficient fishmeal substitutes is becoming more and more concerning (Hardy, 2010; FAO, 2018). So far, plant proteins have been widely reported as the fishmeal substitute in aquafeeds, such as soybean meal (Lim and Dominy, 1990), rapeseed meal (Cheng et al., 2010), cottonseed meal (Lim, 2010), and peanut meal (Liu et al., 2012). However, due to the existence of anti-nutritional factors, unbalanced amino acid profile, and low feed availability, plant proteins often cause many negative impacts on different fishes (Glencross et al., 2020).

As an important plant protein, cottonseed meal has a relatively balanced amino acid profile and is often widely used as a fishmeal substitute. However, the presence of gossypol, a main antinutritional factor in cottonseed meals, brought many adverse effects on the growth and health of fish and severely limited its utilization in aquafeeds (Anderson et al., 2016; Wan et al., 2018). Thus, removing anti-nutritional factors from cottonseed meals will make it better use in aquafeeds. With the recent development of cottonseed processing, the cottonseed protein concentrate (CPC) was obtained by low-temperature extraction with low levels of anti-nutritional factors, such as extremely low gossypol levels (Liu et al., 2020). Therefore, compared to the traditional cottonseed meal, CPC is an excellent plant protein to replace fishmeal in aquafeeds. As a new type of non-grain protein source, CPC was mainly evaluated in replacing dietary fishmeal for the marine fish species in a few studies. It was reported that replacing fishmeal with $60 \%$ CPC did not show adverse effects on growth performance and intestinal health of juvenile golden pompano (Trachinotus ovatus) (Shen et al., 2020). A study in pearl gentian grouper (Epinephelus fuscoguttatus $q \times$ Epinephelus lanceolatu $\sigma^{7}$ ) found that CPC replacing up to $24 \%$ of fishmeal exhibited no negative effects on the growth and intestinal morphology of the fish (Chen et al., 2020). It was also observed that dietary inclusion of CPC suppressed growth performance and immune function of hybrid grouper (Epinephelus fuscoguttatus $q \times$ Epinephelus lanceolatu $\sigma^{7}$ ) (Yin et al., 2018). When fed with a full plant protein diet with soybean protein concentrate and CPC, Japanese seabass (Lateolabrax japonicas) was induced abnormal metabolism in the liver and a fatty liver (Zhang et al., 2019). However, very little information on replacing fishmeal with CPC has been published in freshwater fish species, especially carnivorous fish that usually need a large content of dietary fishmeal.

Largemouth bass (Micropterus salmoides), a typical freshwater carnivorous fish, is one of the most important commercial cultivated fish in China with an annual production of more than 0.6 million tons in 2020 (He et al., 2020; China Fishery Statistical Yearbook, 2021). The dietary protein requirement for largemouth bass is about $48 \%$, and it strongly depends on fishmeal, usually up to $40-50 \%$ (Huang et al., 2017). Therefore, alternative low-cost protein sources for largemouth bass are important for reducing feed prices and increasing the income of fishermen (Zhao et al., 2021). Till now, only one recent study evaluated the combination use of CPC and poultry byproduct meal for replacing fishmeal in largemouth bass and mainly focused on the effects of the supplementation with CPC on growth performance and environmental impacts (Wang et al., 2021), but the investigation of replacing fishmeal with CPC on liver health and intestinal health of largemouth bass, especially at high replacing levels, has not been reported. In the present study, the effects of graded levels of dietary CPC on growth performance, liver health, and intestinal histology were conducted in largemouth bass to evaluate the feasibility for CPC replacing of fishmeal.

\section{MATERIALS AND METHODS}

\section{Experimental Diets}

All ingredients and proximate compositions of the experimental diets are shown in Table 1. Four isonitrogenous and isolipidic experimental diets were formulated to include $0,111,222$, and $333 \mathrm{~g} / \mathrm{kg}$ of CPC, corresponding to replace $0 \%$ (D1), 25\% (D2), $50 \%$ (D3), and 75\% (D4) of dietary fishmeal. The designed protein and lipid content of the experimental diets are based on Huang et al. (2017) and Li et al. (2020), which can satisfy the requirement of largemouth bass. D1 group was used as the control diet with $40 \%$ of fishmeal. All diets were processed through an extruder (TSE65S; Modern Yanggong Machinery S\&T development CO., LTD., Beijing, China) and made into $2 \mathrm{~mm}$ diameter floating pellets. All diets were dried at $60^{\circ} \mathrm{C}$ in an oven and stored at $4^{\circ} \mathrm{C}$. The composition of the CPC used in this experiment is shown in Table 2. Table 3 shows the amino acids profile of CPC and the experimental diets.

\section{Fish and Feeding Trial}

Largemouth bass was purchased from a commercial fish farm (Ezhou, Hubei, China). All fish were fed the control D1 diet for 2 weeks to acclimate the experimental condition. The experiment 
TABLE 1 | Formulation and composition of the experimental diets for largemouth bass.

\begin{tabular}{|c|c|c|c|c|}
\hline \multirow[t]{2}{*}{ Ingredients (g/kg dry matter) } & \multicolumn{4}{|c|}{ Diets $^{1}$} \\
\hline & D1 & D2 & D3 & D4 \\
\hline Fish meal $^{2}$ & 400 & 300 & 200 & 100 \\
\hline Blood meal ${ }^{3}$ & 40 & 40 & 40 & 40 \\
\hline Gluten $^{4}$ & 50 & 50 & 50 & 50 \\
\hline Soybean meal ${ }^{5}$ & 100 & 100 & 100 & 100 \\
\hline Soybean protein concentrate ${ }^{6}$ & 130 & 130 & 130 & 130 \\
\hline Cottonseed protein concetrated ${ }^{7}$ & 0 & 111 & 222 & 333 \\
\hline Cassava starch ${ }^{8}$ & 110 & 110 & 110 & 110 \\
\hline Fish oil ${ }^{9}$ & 32.6 & 35.8 & 39.0 & 42.2 \\
\hline Soybean oil & 32.6 & 35.8 & 39.0 & 42.2 \\
\hline Vitamin and mineral additives ${ }^{10}$ & 10 & 10 & 10 & 10 \\
\hline Monocalcium phosphate & 15 & 15 & 15 & 15 \\
\hline Choline chloride & 1 & 1 & 1 & 1 \\
\hline Microcrystalline cellulose & 78.8 & 61.4 & 44.0 & 26.6 \\
\hline \multicolumn{5}{|c|}{ Proximate chemical compositions (g/kg dry matter) } \\
\hline Moisture & 21.1 & 21.0 & 23.7 & 20.2 \\
\hline Crude protein & 504.3 & 498.3 & 497.4 & 505.4 \\
\hline Crude lipid & 83.2 & 89.7 & 83.3 & 85.5 \\
\hline Free gossypol (mg/kg) & - & 80 & 151 & 284 \\
\hline
\end{tabular}

${ }^{1}$ D1-D4: 0, 25, 50, and $75 \%$ of the fish meal was replaced by cottonseed protein concentrate.

${ }^{2}$ Fish meal: From Superprime, TASA Fish Product Co. Ltd, Peru.

${ }^{3}$ Blood meal: From Beijing Yangyuan Veterinary Medicine Technology Co., Ltd, Beijing, China.

${ }^{4}$ Gluten: From Henan Midaner Trading Co., Ltd, Xinzheng, Henan, China.

${ }^{5}$ Soybean meal: From Qingdao Bohai Agricultural Development Co., Ltd, Qingdao, China.

${ }^{6}$ Soybean protein concentrate: From Yihai grain and oil industry Co., Ltd, Taizhou, Jiangsu, China.

${ }^{7}$ Cottonseed protein concetrated: From Xinjiang Jinlan Plant Protein Co., Ltd, Xinjiang, China.

${ }^{8}$ Cassava starch: From Wuhan Yiteng Starch Co., Ltd, Wuhan, China.

${ }^{9}$ Fish oil: Peru anchovy oil, purchased from Coland Feed Co., Ltd., Wuhan, China.

${ }^{10}$ Vitamin and mineral additives: From Guangdong Nutriera Group, Guangzhou, China.

TABLE 2 | Proximate composition of cottonseed protein concentrate used in the experimental diets ( $\mathrm{g} / \mathrm{kg}$ dry matter).

\begin{tabular}{lc}
\hline Proximate composition & Cottonseed protein concentrate \\
\hline Moisture & 16.7 \\
Crude protein & 615.1 \\
Crude lipid & 23.6 \\
Ash & 81.2 \\
Free gossypol $(\mathrm{mg} / \mathrm{kg})$ & 709 \\
\hline
\end{tabular}

was conducted in an indoor recirculating system with 12 circular plastic tanks (volume $140 \mathrm{~L}$ ). At the beginning of the experiment, all fish were deprived of feed for $24 \mathrm{~h}$. Two hundred and forty healthy fish with an initial body weight of $15.11 \pm 0.02 \mathrm{~g}$ were randomly divided into 4 groups with 3 replicates in each group and 20 fish per replicate.

During the experiment, fish were fed to apparent satiation twice daily at 08:30 and 16:30 for 8 weeks. Daily feed intake
TABLE 3 | Amino acid composition of the experimental diets ( $\mathrm{g} / \mathrm{kg}$ dry matter).

\begin{tabular}{|c|c|c|c|c|c|}
\hline & D1 & D2 & D3 & D4 & CPC \\
\hline \multicolumn{6}{|c|}{ Essential amino acids (EAAs) } \\
\hline Met & 5.80 & 6.46 & 5.12 & 2.71 & 2.96 \\
\hline Lys & 29.63 & 32.35 & 27.21 & 25.26 & 24.68 \\
\hline Thr & 16.88 & 17.92 & 15.96 & 15.85 & 18.08 \\
\hline \|le & 18.33 & 19.25 & 16.94 & 16.74 & 18.46 \\
\hline His & 14.21 & 14.52 & 14.41 & 15.07 & 17.81 \\
\hline Val & 19.94 & 19.87 & 19.60 & 20.26 & 22.95 \\
\hline Leu & 35.78 & 37.23 & 34.07 & 33.78 & 34.08 \\
\hline Arg & 19.42 & 17.16 & 20.91 & 23.96 & 41.85 \\
\hline Phe & 22.52 & 21.71 & 22.52 & 24.45 & 33.33 \\
\hline \multicolumn{6}{|c|}{ Non-essential amino acids (NEAAs) } \\
\hline Asp & 37.09 & 37.25 & 36.47 & 37.41 & 44.87 \\
\hline Ser & 19.06 & 19.13 & 18.80 & 19.89 & 24.16 \\
\hline Glu & 70.77 & 68.74 & 73.14 & 84.61 & 95.16 \\
\hline Gly & 22.14 & 23.15 & 20.91 & 20.25 & 24.54 \\
\hline Ala & 23.17 & 24.39 & 21.25 & 20.34 & 22.56 \\
\hline Cys & 1.78 & 0.48 & 1.53 & 2.67 & 3.83 \\
\hline Pro & 24.47 & 23.71 & 22.83 & 23.37 & 24.03 \\
\hline Tyr & 12.07 & 12.62 & 11.78 & 12.13 & 14.33 \\
\hline
\end{tabular}

was recorded, and uneaten feed was taken out and recorded. This experiment was conducted under $12 \mathrm{~h}$ light: $12 \mathrm{~h}$ dark, and aeration was supplied to each tank $24 \mathrm{~h}$ per day. The water temperature was maintained at $27.0^{\circ} \mathrm{C} \pm 1.0^{\circ} \mathrm{C}, \mathrm{pH} 7-8$, dissolved oxygen $>5.0 \mathrm{mg} / \mathrm{L}$, and ammonia- $\mathrm{N}<0.5 \mathrm{mg} / \mathrm{L}$.

\section{Sampling}

At the end of the feeding trial, all fish were deprived of diets for $24 \mathrm{~h}$. Then, all fish in each tank were bulk weighted to calculate mean final body weight (FBW), weight gain rate (WGR), specific growth rate (SGR), and feed efficiency (FE). Two fish from each tank were randomly selected and frozen at $-20^{\circ} \mathrm{C}$ for the analysis of body composition. Six fish from each tank were anesthetized with $60 \mathrm{mg} / \mathrm{L}$ MS-222, fish body weight and length, viscera, and liver weight of the three fish were recorded to calculate condition factor (K), hepatosomatic index (HSI), and viscerosomatic index (VSI). Three fish from each tank were selected, and liver samples near to the bile were collected, fastfrozen in liquid nitrogen, and stored at $-80^{\circ} \mathrm{C}$ for mRNA expression, enzyme analysis, and western blot analysis. Another three fish from each tank were sampled, and the liver tissues were collected and stored at $-20^{\circ} \mathrm{C}$ to determine the fat content of the liver. The liver and mid-intestine tissues from the three fish per tank were sampled, approximately $5 \mathrm{~mm} \times 5 \mathrm{~mm} \times 5 \mathrm{~mm}$ tissues were fixed in $4 \%$ paraformaldehyde (Boerfu Biotechnology Co., Ltd., Wuhan, China) and stored at $4^{\circ} \mathrm{C}$ no longer than $48 \mathrm{~h}$ for histological analysis.

\section{Biochemical Assays}

Analysis of the proximate composition of the experimental diets and fish samples was executed according to an AOAC protocol 
(Association of Official Analytical Chemists [AOAC], 2003). Moisture content was determined by oven at $105^{\circ} \mathrm{C}$ until constant weight. Ash content was measured by incineration in a muffle furnace (Muffle furnace, Yingshan, Hubei, China) at $550^{\circ} \mathrm{C}$ for $12 \mathrm{~h}$. Crude protein content was measured by the Kjeldahl method using a Kjeltec analyzer unit (Foss Tecator, Höganäs, Sweden), and crude lipid content was measured by the Soxtec system (Soxtec System HT6, Tecator, Höganäs, Sweden). The amino acid contents of all experimental diets were determined after acid hydrolysis in $6 \mathrm{~N} \mathrm{HCl}$ for $24 \mathrm{~h}$ at $11^{\circ} \mathrm{C}$ according to the method of $\mathrm{Tu}$ et al. (2015) and then were analyzed using Hitachi L-8800 Amino Acid Analyzer (Hitachi HighTechnologies Corporation, Tokyo, Japan). Free gossypol levels of the experimental diets and CPC were determined according to the aniline method (Bian et al., 2016). Free gossypol was extracted in the presence of 3-amino-1-propanol with a mixture of 2propanol and hexane. The extracted free gossypol was converted into gossypol-aniline with aniline. Finally, the absorbance of the compound was measured using a spectrophotometer at the wavelength of $440 \mathrm{~nm}$. Liver samples were freeze-dried (Alpha 1-4 LD-plus, Christ, Osterode, Germany), and then the liver lipid content was determined by chloroform/methanol (V/V, 2:1) extraction method.

Activities of alkaline phosphatase (AKP), catalase (CAT), total superoxide dimustase (T-SOD), and malondialdehyde (MAD) content of liver tissues were measured according to the instructions of the commercial kits (Nanjing Jiancheng Bioengineering Institute, Nanjing, Jiangsu, China).

\section{Histological Analysis}

The liver and mid-intestine tissues fixed by $4 \%$ paraformaldehyde were dehydrated in a series of ethanol, embedded in paraffin, and cut into $5 \mu \mathrm{m}$ sections. The sections were stained following the protocols of hematoxylin and eosin (H\&E). Frozen liver sections were fixed in formalin and stained with oil red $\mathrm{O}$. Then the samples were observed and photographed by using a microscope system (DM1000, Leica Microsystems, Germany). The image was analyzed by Image-Pro Plus 6.0.

\section{Quantitative Real-Time PCR Analysis}

Total RNA of the liver was extracted using TRIzol reagent and electrophoresed on an agarose gel to evaluate the integrity. The concentration of extracted RNA was spectrophotometrically quantified with Nanodrop 2000 (Thermo Fisher Scientific, Waltham, MA, United States). In total, $1 \mu \mathrm{g}$ of extracted total RNA was reverse transcribed to cDNA using an M-MLV FirstStrand Synthesis Kit (Invitrogen, Shanghai, China), and the obtained cDNA was used for PCR. The quantitative real-time PCR was performed in LightCycle ${ }^{\S} 480$ II system in a $6 \mu \mathrm{l}$ reaction volume containing LightCycle 480 SYBR Green I Master Mix (Roche, Switzerland). The final reaction volume of $6 \mu \mathrm{l}$ includes $2 \mu \mathrm{l} \mathrm{cDNA}, 0.24 \mu \mathrm{l}$ forward and reverse primer, 0.52 $\mu \mathrm{l} \mathrm{ddH_{2 }}$ O, and $3 \mu \mathrm{l}$ LightCycle 480 SYBR Green I Master Mix. Negative controls were done in the same template which template was replaced with $\mathrm{ddH}_{2} \mathrm{O}$. The qPCR was conducted with the following condition: $95^{\circ} \mathrm{C}$ for $5 \mathrm{~min}$ followed by 40 cycles with $10 \mathrm{~s}$ at $95^{\circ} \mathrm{C}, 20 \mathrm{~s}$ at $\mathrm{Tm}$, and $10 \mathrm{~s}$ at $75^{\circ} \mathrm{C}$. After PCR final cycle, the melted curve was performed to confirm the amplification of a single product with $0.5^{\circ} \mathrm{C}$ increment from $65^{\circ} \mathrm{C}$ to $95^{\circ} \mathrm{C}$. $\beta$-actin and $e f-1 \alpha$, expressed very stable in largemouth bass liver tissue, were chosen as the endogenous reference for normalization. The primers used for transcriptional expression were obtained from previous literatures (Table 4). The results were calculated according to the method of Su et al. (2020).

\section{Western Blot Analysis}

The western blot analysis was carried out according to the method described by Yang et al. (2018). Liver tissues were lysed by RIPA lysis buffer (Beyotime Biotechnology, China) with protease inhibitor cocktail and phosphatase inhibitor cocktail (Roche, Basel, Switzerland). Equal amounts of protein were separated on sodium dodecyl sulphate-polyacrylamide gel electrophoresis (SDS-PAGE) gels and transferred to poly(vinylidene fluoride) (PVDF) membranes. The PVDF membranes were blocked for $1 \mathrm{~h}$ with $5 \%$ milk in TBST buffer and then incubated with anti-phospho-m-target of rapamycin (TOR) (1:1000, \#2971; CST, Danvers, MA, United States), anti-mTOR Antibody (1:1000, \#2972; CST, Danvers, MA, United States), anti-phosphoribosomal protein (S6) $)^{\operatorname{Ser} 235 / 236}$ (1:1000, \#4858; CST, Danvers, MA, United States), anti-S6 (1:1000, \#2217; CST, Danvers, MA, United States), and anti-GAPDH (1:1000, ab8245; Abcam). Horseradish peroxidase-labeled secondary antibodies were used

\begin{tabular}{|c|c|c|c|}
\hline Gene name & Primers & Sequence $5^{\prime}-3^{\prime}$ & Sources \\
\hline \multirow[t]{2}{*}{$\beta$-actin } & $\mathrm{F}$ & ATCGCCGCACTGGTTGTTGAC & Chen et al., 2012 \\
\hline & R & сстGTTGGCTTGGGGTTC & \\
\hline \multirow[t]{2}{*}{$e f-1 \alpha$} & $\mathrm{F}$ & TGCTGCTGGTGTTGGTGAGTT & Yu et al., 2019 \\
\hline & $\mathrm{R}$ & TTCTGGCTGTAAGGGGGCTC & \\
\hline \multirow[t]{2}{*}{$\operatorname{tgf}-\beta$} & $\mathrm{F}$ & GCTCAAAGAGAGCGAGGATG & Yu et al., 2019 \\
\hline & R & ТССТСТАССАТTCGСАATCC & \\
\hline \multirow[t]{2}{*}{$i-10$} & $\mathrm{~F}$ & CGGCACAGAAATCCCAGAGC & Yu et al., 2019 \\
\hline & $\mathrm{R}$ & CAGCAGGCTCACAAAATAAACATCT & \\
\hline \multirow[t]{2}{*}{$i l-11 \beta$} & $\mathrm{F}$ & TTCCCAACAGACAGATGAAGAACTC & Yu et al., 2019 \\
\hline & $\mathrm{R}$ & TGCCTGTGTTCAGCCAGTCAA & \\
\hline \multirow[t]{2}{*}{$\operatorname{tnf}-\alpha$} & $\mathrm{F}$ & CTTCGTCTACAGCCAGGCATCG & Yu et al., 2019 \\
\hline & R & ПTाGGCACACCGACCTCACC & \\
\hline \multirow[t]{2}{*}{$i-15$} & $\mathrm{~F}$ & GTATGCTGCTTCTGTGCCTGG & Yu et al., 2019 \\
\hline & R & AGCGTCAGATTTCTCAATGGTGT & \\
\hline \multirow[t]{2}{*}{ cpt1 } & $\mathrm{F}$ & CATGGAAAGCCAGCCTITAG & Yu et al., 2019 \\
\hline & $\mathrm{R}$ & GAGCACCAGACACGCTAACA & \\
\hline \multirow[t]{2}{*}{ ppara } & $\mathrm{F}$ & CCACCGCAATGGTCGATATG & Yu et al., 2019 \\
\hline & R & TGCTGTTGATGGACTGGGAAA & \\
\hline \multirow[t]{2}{*}{ Fasn } & $\mathrm{F}$ & TGTGGTGCTGAACTCTCTGG & Yu et al., 2019 \\
\hline & $\mathrm{R}$ & CATGCCTAGTGGGGAGTTGT & \\
\hline \multirow[t]{2}{*}{ Tor } & $\mathrm{F}$ & TCAGGACCTCTTCTCATTGGC & Li et al., 2021 \\
\hline & $\mathrm{R}$ & ССТСТСССАССАТGТTТСТСТ & \\
\hline \multirow[t]{2}{*}{ s6 } & $\mathrm{F}$ & GCCAATCTCAGCGTTCTCAAC & Li et al., 2021 \\
\hline & R & CTGCCTAACATCATCCTCCTT & \\
\hline
\end{tabular}

$\bar{F}$, forward primer; $R$, reverse primer; ef- $1 \alpha$, elongation factor $1 \alpha$; tgf- $\beta$, transforming growth factor $\beta$; il-10, interleukin 10; il-11 $\beta$, interleukin $11 \beta$; thf- $\alpha$, tumor necrosis factor $\alpha$; il-15, interleukin; cpt1, carnitine palmitoyl transferase 1; ppara, peroxisome proliferator-activated receptor $\alpha$; tor, target of rapamycin; s6, ribosomal protein. 
to generate a chemiluminescent signal that was detected by ImageQuant LAS 4000mini (GE Healthcare Life Sciences). GAPDH was used as a control.

\section{Calculation and Statistical Analysis}

The WGR, SGR, FE, K, VSI, and HSI were calculated as follows:

$$
\begin{aligned}
& \operatorname{WGR}(\%)=100 \times(\mathrm{FBW}-\text { initial body weight }) / \\
& \text { initial body weight. } \\
& \mathrm{SGR}(\% / \mathrm{d})=100 \times[\mathrm{LnFBW}-\mathrm{Ln} \mathrm{IBW}] / \text { days. } \\
& \mathrm{FE}(\%)=100 \times \text { bodyweightgain } / \text { dry feed consumed. } \\
& \mathrm{K}\left(\mathrm{g} / \mathrm{cm}^{3}\right)=100 \times \mathrm{FBW} /(\text { bodylength })^{3} . \\
& \operatorname{VSI}(\%)=100 \times \text { visceraweight } / \text { whole body weight. } \\
& \mathrm{HSI}(\%)=100 \times \text { liverweight } / \text { whole body weight. }
\end{aligned}
$$

All data were analyzed by SPSS 20 (SPSS Inc., Chicago, IL, United States) for windows. Before one-way ANOVA tested the differences among groups, all data were tested normal distribution and homogeneity of variances. After ANOVA identified the differences, Duncan's multiple range testing was used to identify the significant differences between group means. Effects with a probability of $P<0.05$ were considered statistically significant. All data are presented as means \pm SE.

\section{RESULTS}

\section{Growth Performance}

Effects of replacement of fishmeal with CPC on growth performance, feed utilization, and morphological indices of largemouth bass are shown in Table 5. The WGR in the D4 group was significantly lower $(P<0.05)$ than other groups, and there was no significant difference between D2 or D3 and D1 group $(P>0.05)$. And D4 group had the lowest SGR than other groups. Similar results were found in SGR and FE $(P<0.05)$. In addition, compared to the other groups, replacing fishmeal with CPC by 75\% (D4 group) significantly decreased $(P<0.05) \mathrm{K}$ and HSI of largemouth bass. But no significant differences were observed in VSI of largemouth bass fed different CPC diets (Table 5).

\section{Body Composition}

A significant increase $(P<0.05)$ of body lipid content was observed in the D4 group compared to the control D1 group, but no significant change $(P>0.05)$ of body lipid content was found between the D2 or D3 and D1 groups (Table 6). No changes of crude protein and moisture contents $(P>0.05)$ were found in largemouth bass fed different CPC diets. D4 group had a lower ash content $(P<0.05)$ than D1 and D2 groups (Table 6).

Similar to the results of body lipid content, the liver lipid content of largemouth bass increased with increasing dietary CPC levels, and the D4 group exhibited a significantly higher $(P<0.05)$ content of liver lipid than other groups (Figure 1).
TABLE 5 | The growth performance of largemouth bass fed different cottonseed protein concentrate diets for 8 weeks.

\begin{tabular}{lcccc}
\hline Items & \multicolumn{4}{c}{ Groups } \\
\cline { 2 - 5 } & D1 & D2 & D3 & D4 \\
\hline IBW (g) & $15.2 \pm 0.09$ & $15.1 \pm 0.02$ & $15.0 \pm 0.02$ & $15.2 \pm 0.02$ \\
FBW (g) & $63.1 \pm 1.1^{\mathrm{b}}$ & $63.1 \pm 1.3^{\mathrm{b}}$ & $63.5 \pm 0.01^{\mathrm{b}}$ & $54.9 \pm 2.0^{\mathrm{a}}$ \\
WGR (\%) & $316.4 \pm 7.6^{\mathrm{b}}$ & $317.4 \pm 8.4^{\mathrm{b}}$ & $322.0 \pm 0.6^{\mathrm{b}}$ & $261.8 \pm 12.6^{\mathrm{a}}$ \\
SGR (\%/d) & $2.7 \pm 0.03^{\mathrm{b}}$ & $2.7 \pm 0.04^{\mathrm{b}}$ & $2.70 \pm 0.003^{\mathrm{b}}$ & $2.4 \pm 0.07^{\mathrm{a}}$ \\
FE (\%) & $119.7 \pm 1.0^{\mathrm{b}}$ & $119.9 \pm 0.4^{\mathrm{b}}$ & $118.8 \pm 0.7^{\mathrm{b}}$ & $107.2 \pm 2.1^{\mathrm{a}}$ \\
K (g/cm $\left.{ }^{3}\right)$ & $2.2 \pm 0.02^{\mathrm{b}}$ & $2.2 \pm 0.01^{\mathrm{b}}$ & $2.2 \pm 0.03^{\mathrm{b}}$ & $2.1 \pm 0.05^{\mathrm{a}}$ \\
VSI (\%) & $8.1 \pm 0.2^{\mathrm{y}}$ & $8.4 \pm 0.3$ & $8.1 \pm 0.2$ & $8.5 \pm 0.5^{\mathrm{y}}$ \\
HSI (\%) & $2.9 \pm 0.2^{\mathrm{b}}$ & $3.0 \pm 0.2^{\mathrm{b}}$ & $2.7 \pm 0.2^{\mathrm{ab}}$ & $2.3 \pm 0.2^{\mathrm{a}}$ \\
\hline
\end{tabular}

The results are presented as means $\pm S E$ values in the same column with different superscripts are significantly different $(P<0.05)$.

TABLE 6 | Effects of replacing fish meal with cottonseed protein concentrated on body composition of largemouth bass.

\begin{tabular}{lcccc}
\hline Items & \multicolumn{5}{c}{ Groups } \\
\cline { 2 - 5 } & D1 & D2 & D3 & D4 \\
\hline Crude protein (\%) & $17.19 \pm 0.12$ & $17.29 \pm 0.15$ & $17.24 \pm 0.10$ & $16.98 \pm 0.10$ \\
Crude lipid (\%) & $5.94 \pm 0.29^{\mathrm{a}}$ & $6.34 \pm 0.21^{a b}$ & $6.86 \pm 0.43^{a b}$ & $7.16 \pm 0.33^{\mathrm{b}}$ \\
Ash (\%) & $3.71 \pm 0.07^{\mathrm{b}}$ & $3.85 \pm 0.24^{\mathrm{b}}$ & $3.68 \pm 0.06^{\mathrm{ab}}$ & $3.39 \pm 0.06^{\mathrm{a}}$ \\
Moisture (\%) & $72.37 \pm 0.42$ & $71.80 \pm 0.14$ & $71.63 \pm 0.35$ & $71.95 \pm 0.40$ \\
\hline
\end{tabular}

The results are presented as means $\pm S E$ values in the same column with different superscripts were significantly different $(P<0.05)$.

\section{Histomorphology}

Through the oil red $\mathrm{O}$ staining of the liver, it was found that fish in the D4 group showed an aggravated fat deposition (Figure 2). The hepatocytes in fish fed the control D1 diet showed clear boundary with vacuolated cytoplasm and no obvious vacuolar degeneration and inflammatory cells infiltration (Figure 3). However, with the increasing dietary CPC levels, largemouth bass a exhibited different degree of hepatocyte degeneration and inflammatory cells infiltration. Compared to the control D1 group, the hepatocytes of fish in the D4 group exhibited severe abnormalities with a disappeared boundary of hepatocytes, hepatocytes volume shrinkage, nucleus pyknosis, aggravated vacuolar degeneration, and inflammatory cells infiltration (Figure 3).

As shown in Figure 4, the structure of the mid-intestine in the D1, D2, or D3 group is normal. However, when $75 \%$ of dietary fishmeal was replaced by CPC, the intestinal villi of largemouth bass appeared shorter and sparse with severe epithelial damage in the D4 group. D4 group exhibited significantly lower $(P<0.05)$ villus height and width than the D1 group (Table 7).

\section{Liver Antioxidant Enzymes}

Fish in the D2 group had the highest activity of liver AKP, and the D4 group had the lowest activity of AKP among all groups (Figure 5). The activities of CAT and T-SOD in the D4 group were significantly higher $(P<0.05)$ than other groups. No 


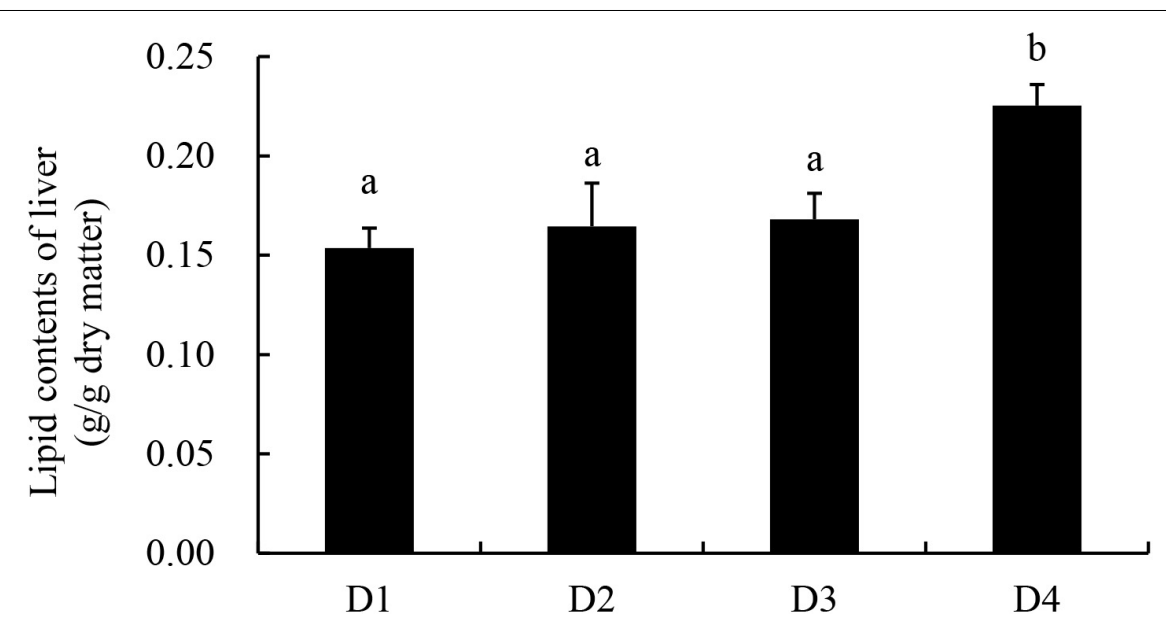

FIGURE 1 | Lipid content of liver tissues in largemouth bass fed different cottonseed protein concentrate diets for 8 weeks. Bars assigned with different letters were significantly different $(P<0.05)$.
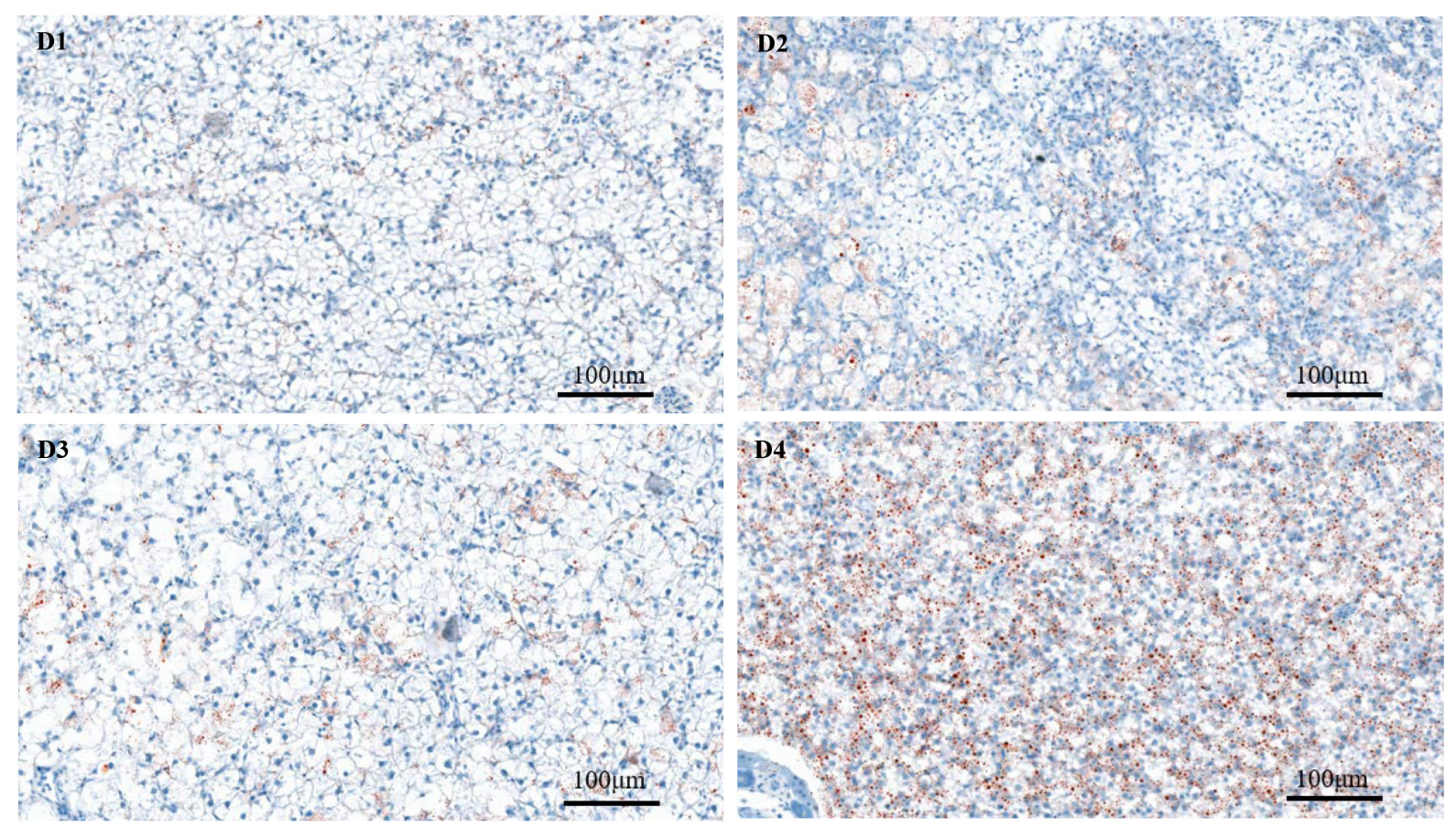

FIGURE 2 | Oil Red O staining (200x) of fat deposition of live tissues in largemouth bass fed different cottonseed protein concentrate diets for 8 weeks. Red points represent lipid droplets. Scale bar: $100 \mu \mathrm{m}$. D1-D4: 0, 25, 50, and 75\% of the fish meal was replaced by cottonseed protein concentrate.

significant difference in the MDA content was found $(P>0.05)$ in largemouth bass fed different CPC diets (Figure 5).

\section{Gene Expression and Protein Level in Liver Tissues}

The transcriptional level of inflammation-related genes in liver tissues is shown in Figure 6. Anti-inflammatory-related cytokines transforming growth factor $\beta$ (tgf- $\beta$ ), interleukin 10 (il-10), and interleukin $11 \beta($ il-11ß) were significantly induced in the D2 group, but were significantly downregulated in the D4 group $(P<0.05)$. However, the mRNA expression of pro-inflammatory cytokines tnf- $\alpha$ and $i l-15$ was not affected by the replacement of fishmeal by CPC $(P>0.05)$.

The relative expression of lipid metabolism-related genes in the liver is presented in Figure 7. The genes related to lipolysis peroxisome proliferator-activated receptor $\alpha$ (ppar $\alpha)$ and carnitine palmitoyl transferase 1 (cpt1) were downregulated with the increasing dietary CPC levels. The transcriptional level of cpt1 was significantly higher $(P<0.05)$ in the D2 group 

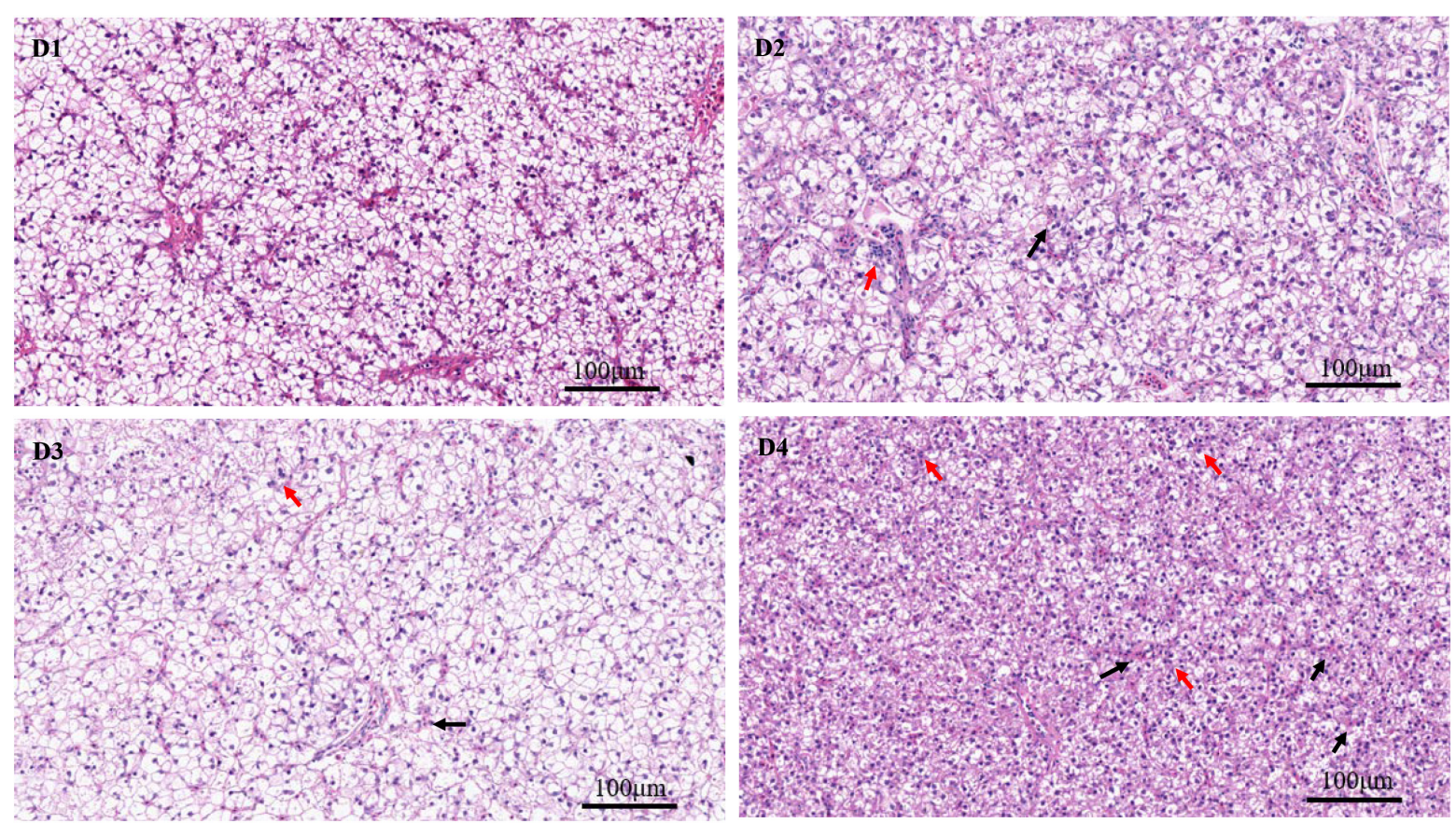

FIGURE 3 | H \& E staining $(200 \times)$ ) of liver histomorphology in largemouth bass fed different cottonseed protein concentrate diets for 8 weeks (black arrows show the inflammatory cells infiltration, and red arrows show the nucleus pyknosis). Scale bar: $100 \mu \mathrm{m}$. D1-D4: 0, 25, 50, and 75\% of the fish meal was replaced by cottonseed protein concentrate.
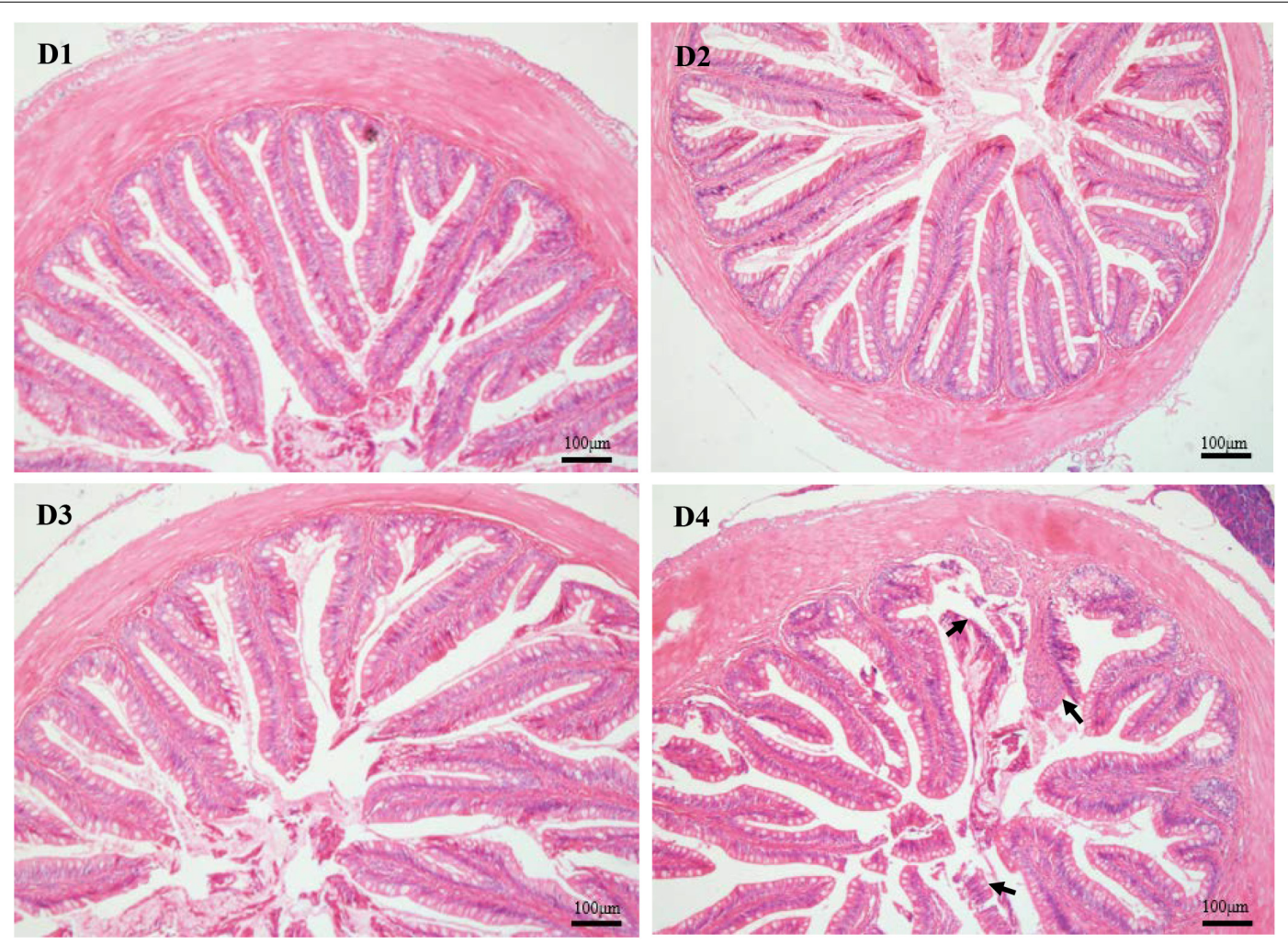

FIGURE 4 | H \& E staining $(100 \times)$ of mid-intestinal histology in largemouth bass fed different cottonseed protein concentrate diets for 8 weeks (black arrows show the epithelial damage). Scale bar: $100 \mu \mathrm{m}$. D1-D4: 0, 25, 50, and 75\% of the fish meal was replaced by cottonseed protein concentrate. 
TABLE 7 | Histological parameters of mid-intestinal in largemouth bass fed different cottonseed protein concentrate diets.

\begin{tabular}{lcc}
\hline Groups & Villus height $(\boldsymbol{\mu m})$ & Villus width $(\boldsymbol{\mu} \mathbf{m})$ \\
\hline D1 & $564.43 \pm 20.67^{\mathrm{b}}$ & $110.81 \pm 3.89^{\mathrm{b}}$ \\
D2 & $566.98 \pm 15.60^{\mathrm{b}}$ & $99.93 \pm 6.01^{\mathrm{ab}}$ \\
D3 & $519.32 \pm 13.41 \mathrm{a}^{\mathrm{b}}$ & $99.99 \pm 2.45^{\mathrm{ab}}$ \\
D4 & $476.63 \pm 8.48^{\mathrm{a}}$ & $96.12 \pm 3.52^{\mathrm{a}}$ \\
\hline
\end{tabular}

The results are presented as means \pm SE values in the same column with different superscripts were significantly different $(P<0.05)$.

than in the other groups. However, the relative expression of fasn was not significantly affected $(P>0.05)$ by the replacing of fishmeal with CPC.

The relative expression of TOR and S6was downregulated in fish with increasing dietary CPC levels (Figures 8A,B). Compared to the control D1 group, the D2 group did not exhibit a negative regulation $(P>0.05)$ of gene expression of TOR and S6. However, D4 group had the lowest level of relative expression of tor among all groups (Figures $\mathbf{8 A}, \mathbf{B}$ ). The corresponding protein levels of TOR and S6 were also detected. The phosphorylation activation of TOR and S6 was significantly downregulated $(P<0.05)$ in the D4 group (Figures 8C-E).

\section{DISCUSSION}

Many studies have been conducted to investigate the effects of replacing dietary fishmeal with plant protein on the growth performance of fish (Yin et al., 2018; Abbasi et al., 2020; Shen et al., 2020; Yaghoubi et al., 2020). In the present study, dietary replacement of $25 \%$ or $50 \%$ of dietary fishmeal by CPC had no negative effects on growth performance, but dietary substitution of $75 \%$ fishmeal by CPC significantly decreased the growth performance of the fish. The present results were supported by previous results that no adverse effects on growth performance were found in juvenile golden pompano when dietary fishmeal was replaced by CPC at a moderate level, but high substitution led to a significant negative effect on the growth performance of fish (Shen et al., 2020). It was also reported that in hybrid grouper, WGR and SGR were significantly declined when over $48 \%$ of dietary fishmeal was replaced by CPC (Yin et al., 2018). These findings indicated that a suitable replacement level of CPC in the diet showed no negative effects and even had positive effects on growth performance. It has been reported that a suitable CPC level in the diet may improve the amino acids profile in feed and make the proportion of amino acids more reasonable and suitable for aquatic animals (Elangovan and Shim, 2000; Yin et al., 2018). However, the high incorporation of CPC in diets impaired the growth performance of largemouth bass. Dietary CPC inclusion was often accompanied by poor palatability, imbalanced amino acid composition, and anti-nutritional factors (Chen et al., 2020; He et al., 2021). When replacing fishmeal with a high level, it would significantly affect the growth of fish (Yin et al., 2018; He et al., 2021). Our research results demonstrated that $111-222 \mathrm{~g} / \mathrm{kg}$ $\mathrm{CPC}$ is the suitable replacement level for largemouth bass.

The liver is the most important organ of body metabolism (Tamura and Shimomura, 2005). In the present study, the lipid

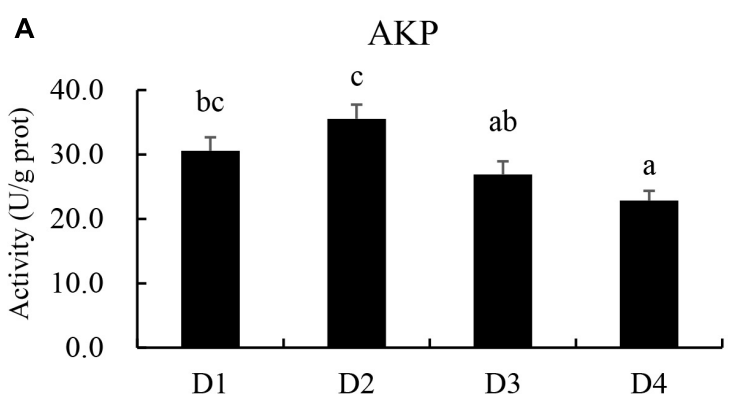

C

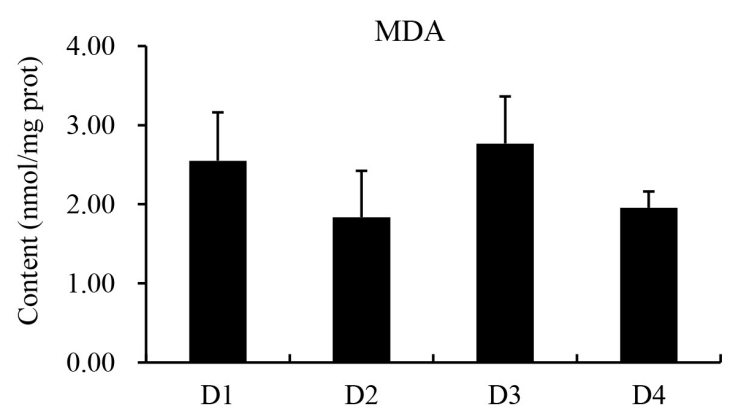

B

CAT

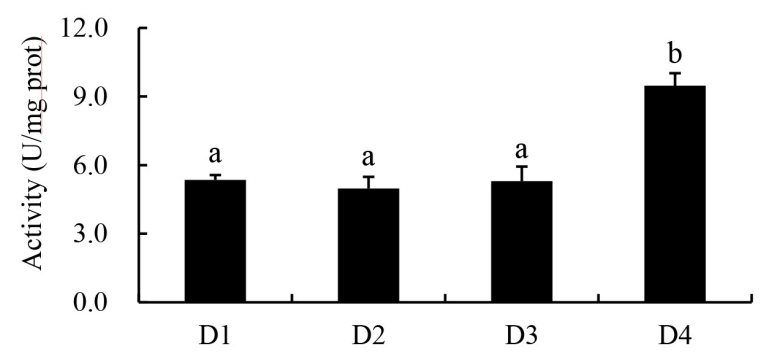

D

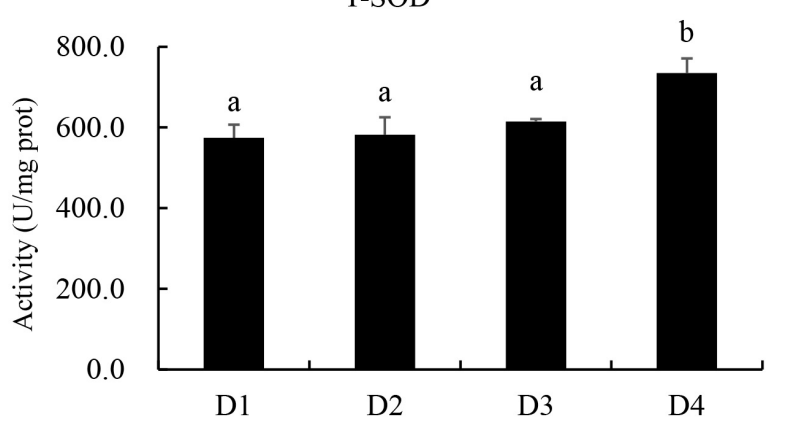

FIGURE 5 | Effects of replacing fish meal with cottonseed protein concentrate on liver antioxidant capacities of largemouth bass. (A) AKP, alkaline phosphatase. (B) CAT, catalase. (C) MDA, malondialdehyde. (D) T-SOD, total superoxide dimustase. Bars assigned with different letters were significantly different (P < 0.05). 

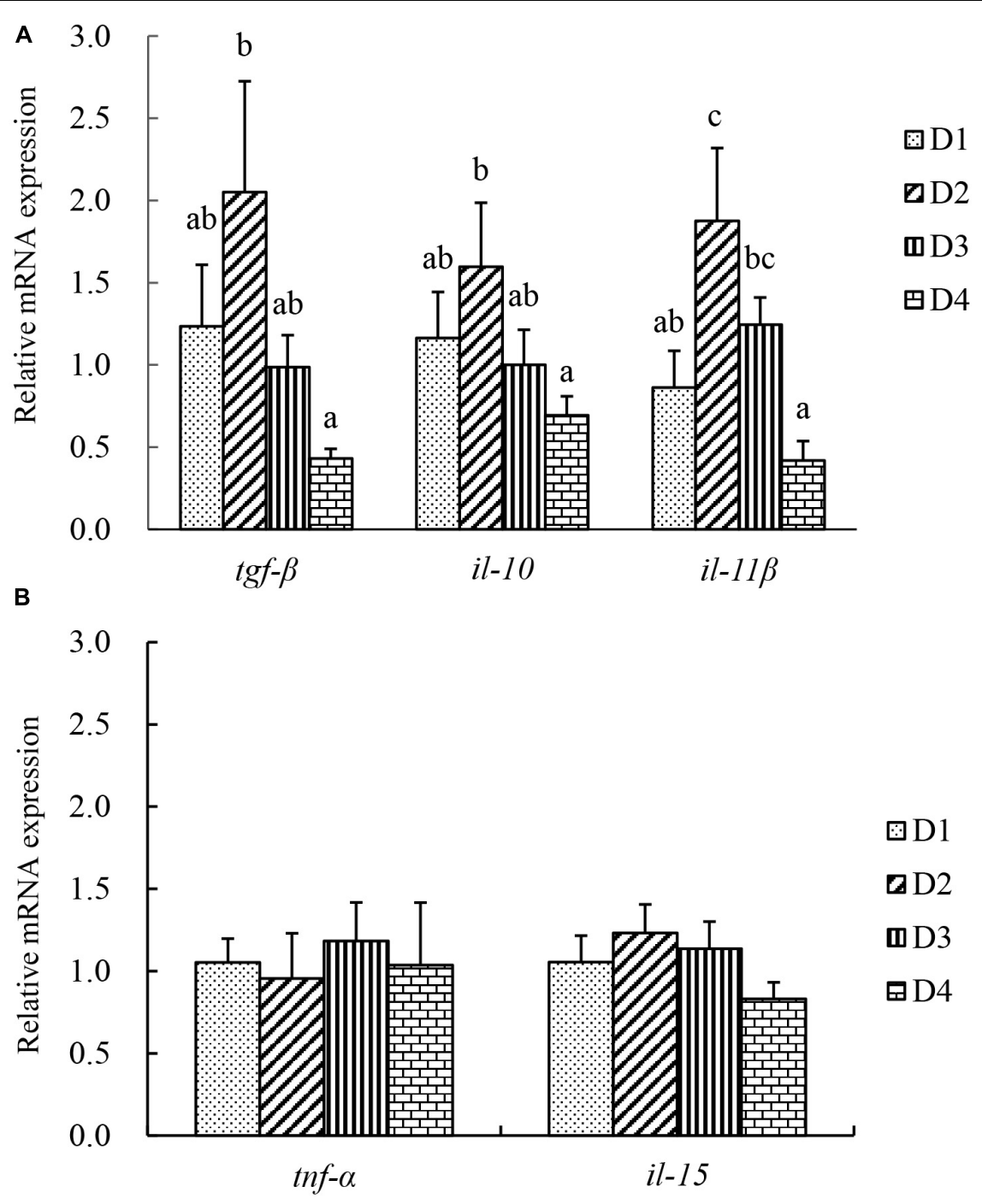

FIGURE 6 | The transcriptional level of inflammation-related genes in liver of largemouth bass fed different cottonseed protein concentrate diets for 8 weeks. (A) Anti-inflammatory related cytokines, transforming growth factor $\beta$ (tgf- $\beta$ ), interleukin 10 (il-10), and interleukin 11 (il-11 $\beta$ ). (B) Pro-inflammatory related cytokines, tumor necrosis factor $\alpha(\operatorname{tnf}-\alpha)$, and interleukin (il-15). Bars assigned with different letters were significantly different $(P<0.05)$.

deposition in liver tissues of largemouth bass was significantly increased in the D4 group. Similar results were reported that there was obvious fat deposition in liver tissues of hybrid grouper fed diet with the replacement of $36 \%$ fishmeal by CPC (Yin et al., 2018). Zhang et al. (2019) also reported that fatty liver was induced in Japanese seabass fed a full plant protein diet of soybean protein and CPC which was explained that a full plant protein diet caused nutrient and energy metabolic disorder and then induced fatty liver. In this study, 75\% CPC replacement level might induce metabolic disorder in the liver. This was supported by the lipid metabolism-related gene expression (cpt1, ppara, and fasn) and histological results. In the present study, the D4 group with replacement of $75 \%$ fishmeal by CPC had significant downregulation of TOR signaling, lipolysis-related genes, and anti-inflammatory cytokine genes, which indicated that the metabolism of fish was significantly affected by the high substitution of CPC. In addition, from the histomorphology of the liver, we found that compared to the control D1 group, the hepatocytes of largemouth bass fed diet with the replacement of 75\% fishmeal by CPC exhibited serious degeneration, volume shrinkage, and inflammatory cells infiltration. The results were well agreed with a previous study that juvenile turbot fed diet with $45 \%$ of fishmeal replaced by cottonseed meal led to smaller liver cell and liver damage (Bian et al., 2016). From the mid-intestinal histology, abnormal shorter and sparse with severe epithelial damage in fish was observed in the D4 group. Consistently, many researchers have reported that high plant proteins inclusion diet-induced intestinal structure damage in juvenile turbot (Bian et al., 2016), Japanese seabass (Wang et al., 2016), and largemouth bass (He et al., 2020). Therefore, all these indicated that $75 \%$ of dietary fishmeal replaced by CPC might induce abnormal liver fat deposition, liver, and intestinal 

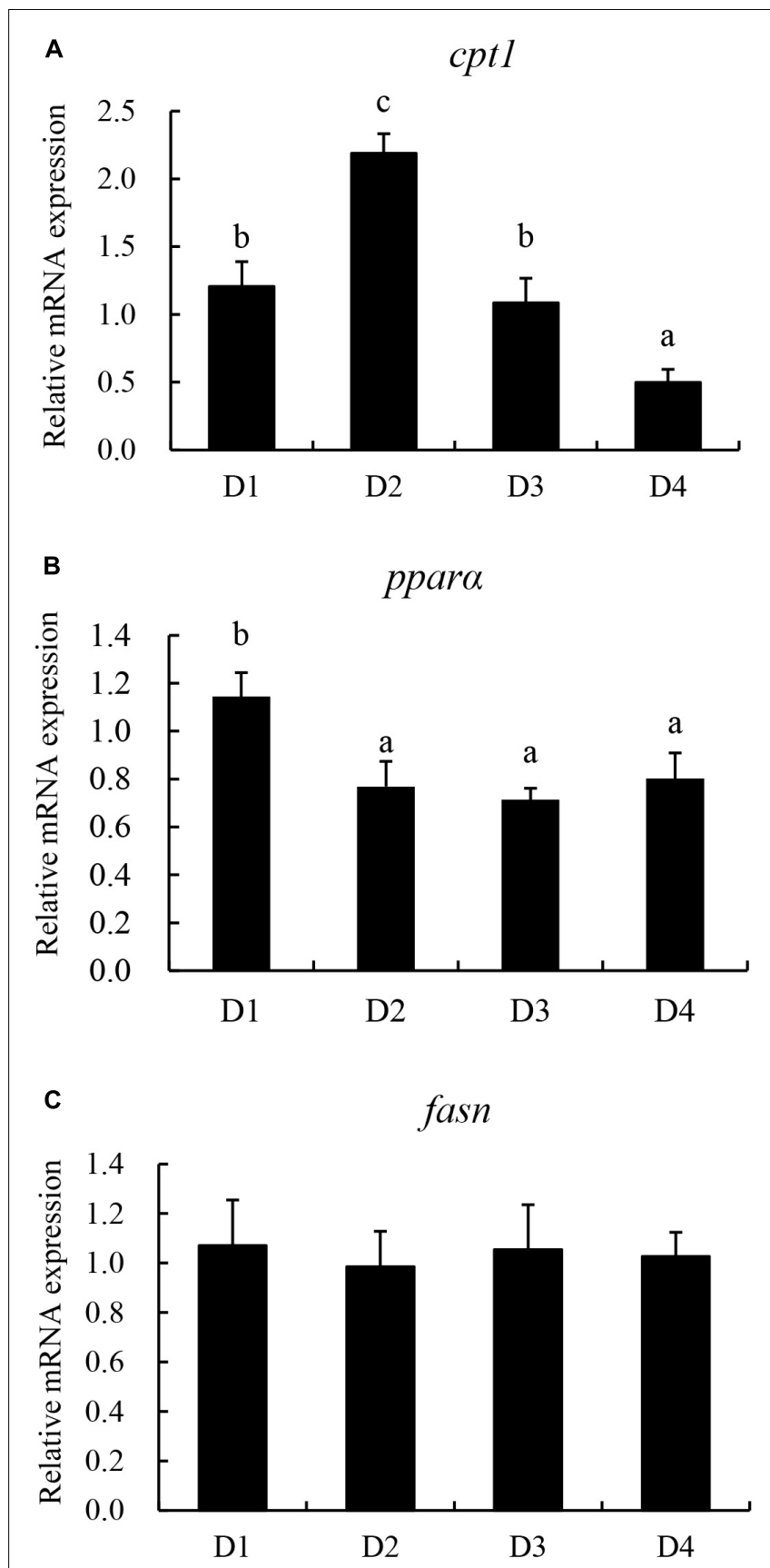

FIGURE 7 | Effects of replacing fishmeal with cottonseed protein concentrate on the transcriptional expression of lipid metabolism-related genes in liver of largemouth bass. (A) Carnitine palmitoyl transferase 1 (cpt1). (B) Peroxisome proliferator-activated receptor $\alpha$ (ppar $\alpha$ ). (C) Fatty acid synthase (fasn). Bars assigned with different letters were significantly different $(P<0.05)$.

damage of largemouth bass which would be closely related to the decreased growth of the fish.

Transforming growth factor $\beta$, il-10, and il-11 $\beta$ are the antiinflammatory cytokines, and tnf- $\alpha$ and il-15 are two important pro-inflammatory cytokines, which play an important role in inflammatory processes and immune response to protect the liver from cell injury and initiate tissue regeneration ( $\mathrm{Yu}$ et al., 2019; Zhang et al., 2019). In the present study, the gene expressions of $\operatorname{tg} f-\beta, i l-10$, and $i l-11 \beta$ were significantly downregulated with the increasing dietary CPC levels, and these genes exhibited the highest transcriptional levels in the D2 group. Anti-inflammatory cytokines can prevent abnormal expression of immune response (Hoseinifar et al., 2018). The present results observed upregulation of anti-inflammatory cytokines in the D2 group (substitution of 25\% fishmeal) and downregulation of antiinflammatory cytokines in the D4 group (substitution of 75\% fishmeal), together with the no changes of pro-inflammatory cytokines among all groups. All these indicated that low substitution of fishmeal by CPC caused an improved immune response of largemouth bass, but excessive substitution led to a significant decline in immune status which would also be closely related to the decreased growth and tissue damage of the fish.

In mammals and fish, the TOR signaling pathway, such as tor, s6, and so on, plays a key role in sensing nutrients and regulates organismal growth and homeostasis by coordinating the anabolism and catabolism (Lansard et al., 2010; Roux and Topisirovic, 2012; Bian et al., 2017). Furthermore, there is a positive correlation between the phosphorylation activation of the TOR pathway and growth in fish (Song et al., 2016; Bian et al., 2017). In the present study, the transcriptional and protein levels of tor and $s 6$ were significantly downregulated in fish of the D4 group (high substitution of $75 \%$ fishmeal). Similar results were reported by Zhou et al. (2018) that high dietary inclusion of plant protein decreased the relative expression of TOR pathway-related genes. Some studies have shown that gossypol and imbalanced amino acids can suppress TOR signaling (Tu et al., 2015; Bian et al., 2017). In the present study, high dietary inclusion of CPC contained high gossypol and imbalanced amino acids, which negatively regulated the TOR pathway. This indicated that the impaired TOR signaling pathway is one reason for the negative effect on growth performance in largemouth bass fed D4 diet.

In this study, the content of whole body protein and moisture were not affected by different dietary CPC inclusion. Similar results were reported in Oncorhynchus mykiss (Zhao et al., 2021) and Litopenaeus vannamei (Wan et al., 2018), which found that whole body protein and moisture contents were not significantly changed among CPC substitution groups. In the present study, whole body lipid content of largemouth bass was increased with the increasing dietary CPC levels. The result was consistent with previous results that the replacement of fishmeal by low-gossypol cottonseed meal increased whole body lipid content of juvenile southern flounder (Paralichthys lethostigma) and high dietary inclusion of low-gossypol cottonseed meal impaired the liver function of the fish (Alam et al., 2018). The present results of the increase of lipid content in whole body and liver tissues of fish with the increasing dietary CPC levels could be due to the significant downregulation of lipolysis genes and no change of lipogenesis in fish fed diets with high substitutions by CPC.

Compared to fishmeal, plant proteins are characterized as a high carbohydrate source (Zhang et al., 2019). High dietary carbohydrates often caused lipid metabolism disorder and caused lipid deposition in the liver (Zhang et al., 2020). In the current study, high dietary CPC along with high carbohydrates maybe 
A

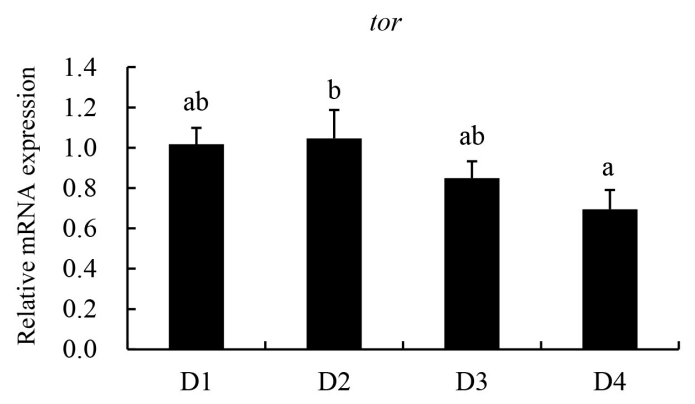

B

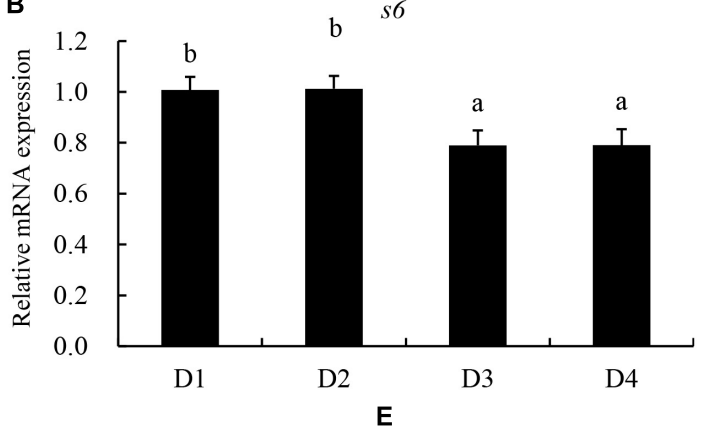

C

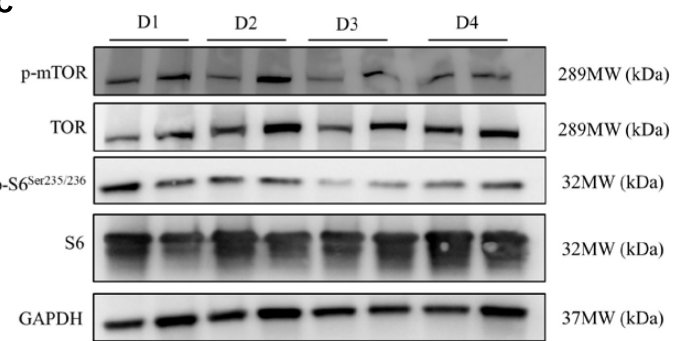

D

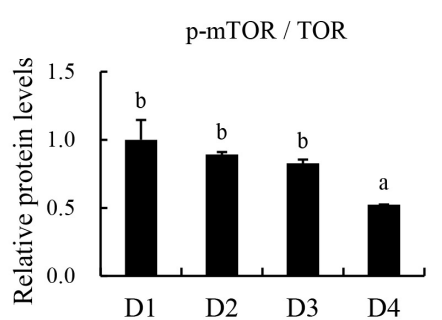

FIGURE 8 | The transcriptional and protein level of TOR and S6 in the liver of largemouth bass fed different cottonseed protein concentrate diets for 8 weeks. (A) Relative mRNA expression of target of rapamycin (tor). (B) Relative mRNA expression of ribosomal protein (s6). (C-E) Western blot analysis for protein levels of tor and s6. Bars assigned with different letters were significantly different $(P<0.05)$. D1-D4: 0, 25, 50, and $75 \%$ of the fish meal was replaced by cottonseed protein concentrate.

one important reason accounting for liver lipid deposition in largemouth bass. ppar $\alpha$ is one of the important transcriptional factors in regulating fatty acids oxidation and lipolysis (Goto et al., 2011). Similarly, cpt1 plays an important role in mediating long-chain fatty acids oxidation (Kerner and Hoppel, 2000). In the present study, the gene expression of ppara and $c p t 1$ were lower in the D4 group than the D1 group. A similar result was reported that juvenile hybrid grouper fed a high level of dietary mixture plant protein downregulated ppar $\alpha$ and cpt1 mRNA expression (Ye et al., 2019). fasn is an important enzyme involved in lipid synthesis, the mRNA level of fasn was not affected by different CPC inclusion level. The current results indicated that high-level dietary CPC inclusion caused lipid deposition in the liver of largemouth bass.

The organism antioxidant enzyme activity is an important indicator in reflecting the status of oxidative stress in fish response to external stimuli (Deng et al., 2015). T-SOD and CAT activities can reflect the ability of the body against oxidative stress (Yuan et al., 2019). In the present study, T-SOD and CAT were significantly increased in largemouth bass fed D4 diet, indicating that largemouth bass had suffered from oxidative stress caused by high lever CPC replacement, increased T-SOD and CAT activities moderated the damage caused by oxidative stress. Similar results were obtained in hybrid grouper (Yin et al., 2018). MDA is one of the important indicators of lipid peroxidation, it has a strong biotoxicity to cells (Parvez and Raisuddin, 2005). In the present study, there was no significant difference in MDA content among groups, which indicated that increased T-SOD and CAT mitigated the lipid peroxidation caused by oxidative stress. Similar results were observed in juvenile Trachinotus ovatus and Penaeus monodon, the MDA content in liver was not influenced by different CPC replacement level (Shen et al., 2020; Jiang et al., 2021). AKP is an important enzyme reflecting the health of organism, has a potential protective effect on fish (Ghehdarijani et al., 2016). In the current study, D2 group showed the highest AKP activity, but the D4 group had the lowest AKP activity among all groups. The present results indicated that oxidative stress occurred when $75 \%$ of dietary fishmeal was replaced by $\mathrm{CPC}$, which may be one of the reasons for the negative effect on growth performance in largemouth bass fed high-level CPC diets.

\section{CONCLUSION}

In the present study, CPC can replace up to $50 \%$ of dietary fishmeal without any adverse influence on the growth, body composition, antioxidant indices, and intestinal health of largemouth bass. However, high dietary inclusion of CPC (75\% replacement of fishmeal) would cause significant negative effects on the growth performance, liver, and intestine health of the fish. The present results indicated that suitable substitution of fishmeal by less than $222 \mathrm{~g} \mathrm{CPC} / \mathrm{kg}$ diet had a positive effect on growth performance of fish, but an excessive substitution of $75 \%$ fishmeal by CPC led to the suppressed growth, liver, and intestinal damage of largemouth bass.

\section{DATA AVAILABILITY STATEMENT}

The original contributions presented in the study are included in the article/supplementary material, further inquiries can be directed to the corresponding author. 


\section{ETHICS STATEMENT}

The animal study was reviewed and approved by the Institute of Hydrobiology, Chinese Academy of Sciences.

\section{AUTHOR CONTRIBUTIONS}

$\mathrm{DH}$ and YL designed the study. YL performed the experimental work and wrote the manuscript under the direction of DH. QL and LX contributed to perform the experiment. YY helped with biochemical analysis. JS, YG, ZZ, and HL gave helps for analyzing data. JJ, XZ, and SX provided suggestions on experimental design and manuscript writing. All authors contributed to the article and approved the submitted version.

\section{REFERENCES}

Abbasi, A., Oujifard, A., Torfi, M. M., Habibi, H., and Nafisi, B. M. (2020). Dietary simultaneous replacement of fish meal and fish oil with blends of plant proteins and vegetable oils in yellowfin seabream (Acanthopagrus latus) fry: Growth, digestive enzymes, antioxidant status and skin mucosal immunity. Aquacult. Nutr. 26, 1131-1111. doi: 10.1111/anu.13070

Alam, M. S., Watanabe, W. O., Carroll, P. M., Gabel, J. E., Corum, M. A., et al. (2018). Evaluation of genetically-improved (glandless) and genetically-modified low-gossypol cottonseed meal as alternative protein sources in the diet of juvenile southern flounder Paralichthys lethostigma reared in a recirculating aquaculture system. Aquaculture 489, 36-45.

Anderson, A. D., Alam, M. S., Watanabe, W. O., Carroll, P. M., Wedegaertner, T. C., and Dowd, M. K. (2016). Full replacement of menhaden fish meal protein by low-gossypol cottonseed flour protein in the diet of juvenile black sea bass Centropristis striata. Aquaculture 464, 618-628.

Association of Official Analytical Chemists [AOAC] (2003). Official methods of analysis. Rockville, MD: AOAC.

Bian, F., Zhou, H., He, G., and Wang, C. (2016). Effects of replacing fishmeal with different cottonseed meals on growth, feed utilization, haematological indexes, intestinal and liver morphology of juvenile turbot (Scophthalmus maximus L.). Aquacult. Nutr. 23, 1429-1439. doi: 10.1111/anu.12518

Bian, F. Y., Jiang, H. W., Man, M. S., Mai, K. S., Zhou, H. H., Xu, W., et al. (2017). Dietary gossypol suppressed postprandial TOR signaling and elevated ER stress pathways in turbot (Scophthalmus maximus L.). Am. J. Physiol.: Endocrinol. Metab. 312, E37-E47. doi: 10.1152/ajpendo.00285.2016

Chen, G. F., Yin, B., Liu, H. Y., and Tan, B. P. (2020). Effects of fishmeal replacement with cottonseed protein concentrate on growth, digestive proteinase, intestinal morphology and microflora in pearl gentian grouper (Epinephelus fuscoguttatus o $\times$ Epinephelus lanceolatu $\left.\sigma^{7}\right)$. Aquacult. Res. 51, 2870-2884.

Chen, Y. J., Liu, Y. J., Yang, H. J., Yuan, Y., Liu, F. J., Tian, L. X., et al. (2012). Effect of dietary oxidized fish oil on growth performance, body composition, antioxidant defense mechanism and liver histology of juvenile largemouth bass Micropterus salmoides. Aquacult. Nutr. 18, 321-331. doi: 10.1111/j.1365-2095. 2011.00900.x

Cheng, Z. Y., Ai, Q. H., Mai, K. S., Xu, W., Ma, H. M., Li, Y., et al. (2010). Effects of dietary canola meal on growth performance, digestion and metabolism of Japanese seabass. Lateolabrax japonicus. Aquaculture. 305, 102-108. doi: 10. 1016/j.aquaculture.2010.03.031

China Fishery Statistical Yearbook (2021). Fishery Bureau. Beijing: Ministry of Agriculture, China Agriculture Press.

Deng, J. M., Mai, K. S., Chen, L. Q., Mi, H. F., and Zhang, L. (2015). Effects of replacing soybean meal with rubber seed meal on growth, antioxidant capacity, non-specific immune response, and resistance to Aeromonas hydrophila in tilapia (Oreochromis niloticus $\times$ O. aureus). Fish Shellfish Immunol. 44, 436-444. doi: 10.1016/j.fsi.2015.03.018

Elangovan, A., and Shim, K. F. (2000). The influence of replacing fish meal partially in the diet with soybean meal on growth and body composition of juvenile

\section{FUNDING}

This work was funded by the National Key R\&D Program of China (2019YFD0900200), China Agriculture Research System of MOF and MARA (CARS-46), National Natural Science Foundation of China (31972771, 31672670, and 31972805), Fund Project in State Key Laboratory of Freshwater Ecology and Biotechnology (2019FBZ02 and 2019FBZ05), Hubei High-Tech Innovation and Business Incubation Center (2019-02-055), and Science and Technology Project of Wuhan (2019020701011459).

\section{ACKNOWLEDGMENTS}

The authors are grateful to Guanghan Nie for his technical help.

tin foil barb (Barbodes altus). Aquaculture 189, 133-144. doi: 10.1016/S00448486(00)00365-3

FAO (2018). The State of World Fisheries and Aquaculture 2018: Meeting the Sustainable Development Goals. Rome: FAO.

Ghehdarijani, M. S., Hajimoradloo, A., Ghorbani, R., and Roohi, Z. (2016). The effects of garlic-supplemented diets on skin mucosal immune responses, stress resistance and growth performance of the caspian roach (Rutilus rutilus) fry. Fish Shellfish Immunol. 49, 79-83. doi: 10.1016/j.fsi.2015.12.021

Glencross, B. D., Baily, J., Berntssen, M. H., Hardy, R., MacKenzie, S., and Tocher, D. R. (2020). Risk assessment of the use of alternative animal and plant raw material resources in aquaculture feeds. Rev. Aquacult. 12, 703-758. doi: 10. 1111/raq. 12347

Goto, T., Lee, J., Teraminami, A., Kim, Y., Hirai, S., Uemura, T., et al. (2011). Activation of peroxisome proliferator-activated receptor-alpha stimulates both differentiation and fatty acid oxidation in adipocytes. J. Lipid Res. 52, 873-884. doi: 10.1194/jlr.M011320

Hardy, R. W. (2010). Utilization of plant proteins in fish diets: Effects of global demand and supplies of fishmeal. Aquacult. Res. 41, 770-776. doi: 10.1111/j. 1365-2109.2009.02349.x

He, M., Li, X. Q., Poolsawat, L., Guo, Z. H., Yao, W. X., Zhang, C. Y., et al. (2020). Effects of fish meal replaced by fermented soybean meal on growth performance, intestinal histology and microbiota of largemouth bass (Micropterus salmoides). Aquacult. Nutr. 26, 1058-1071. doi: 10.1111/anu. 13064

He, Y. F., Guo, X. W., Tan, B. P., Dong, X. H., and Chi, S. Y. (2021). Replacing fishmeal with cottonseed protein concentrate in feed for pearl gentian groupers (Epinephelus fuscoguttatus $q \times$ E. lanceolatus $\left.\sigma^{7}\right)$ : Effects on growth and expressions of key genes involved in appetite and hepatic glucose and lipid metabolism. Aquacult. Rep. 20:100710. doi: 10.1016/j.aqrep.2021.100710

Hoseinifar, S. H., Zou, H. K., Doan, H. V., Miandare, H. K., and Hoseini, S. M. (2018). Evaluation of some intestinal cytokines genes expression and serum innate immune parameters in common carp (Cyprinus carpio) fed dietary loquat (Eriobotrya japonica) leaf extract. Aquacult. Res. 49, 120-127. doi: 10. 1111/are. 13440

Huang, D., Wu, Y. B., Lin, Y. Y., Chen, J. M., Karrow, N., Ren, X., et al. (2017). Dietary protein and lipid requirements for juvenile largemouth bass, Micropterus salmoides. J. World Aquacult. Soc. 48, 782-790. doi: 10.1111/jwas. 12417

Jiang, S., Chen, Z. B., Zhou, F. L., Yang, Q. B., Huang, J. H., Yang, L. S., et al. (2021) Study on partial replacement of fish meal with concentrated dephenolized cottonseed protein in feed of Penaeus monodon. Aquacult. Res. 52, 3871-3881. doi: 10.1111 /are.15231

Kerner, J., and Hoppel, C. (2000). Fatty acid import into mitochondria. BBA-Mol Cell Biol L. 1486, 1-17. doi: 10.1016/S1388-1981(00)00044-5

Lansard, M., Panserat, S., Plagnes-Juan, E., Seiliez, I., and Skiba-Cassy, S. (2010). Integration of insulin and amino acid signals that regulate hepatic metabolismrelated gene expression in rainbow trout: role of tor. Amino Acids 39, 801-810. doi: 10.1007/s00726-010-0533-3 
Li, S. L., Dai, M., Qiu, H. J., and Chen, N. S. (2021). Effects of fishmeal replacement with composite mixture of shrimp hydrolysate and plant proteins on growth performance, feed utilization, and target of rapamycin pathway in largemouth bass, Micropterus salmoides. Aquaculture 533:736185. doi: 10.1016/ j.aquaculture.2020.736185

Li, X. Y., Zheng, S. X., Ma, X. K., Cheng, K. M., and Wu, G. Y. (2020). Effects of dietary protein and lipid levels on the growth performance, feed utilization, and liver histology of largemouth bass (Micropterus salmoides). Amino Acids 52, 1043-1061. doi: 10.1007/s00726-020-02874-9

Lim, C. (2010). Substitution of cottonseed meal for marine animal protein in diets for Penaeus vannamei. J. World Aquacult. Soc. 27, 402-409.

Lim, C., and Dominy, W. (1990). Evaluation of soybean meal as a replacement for marine animal protein in diets for shrimp (Penaeus vannamei). Aquaculture 87, 53-63. doi: 10.1016/0044-8486(90)90210-E

Liu, H., Dong, X. H., Tan, B. P., Du, T., Zhang, S., Yang, Y. Z., et al. (2020). Effects of fish meal replacement by low-gossypol cottonseed meal on growth performance, digestive enzyme activity, intestine histology and inflammatory gene expression of silver sillago (Sillago sihama Forsskal) (1775). Aquacult. Nutr. 26, 1724-1735. doi: 10.1111/anu.13123

Liu, X. H., Ye, J. D., Wang, K., Kong, J. H., Yang, W., and Zhou, L. (2012). Partial replacement of fish meal with peanut meal in practical diets for the Pacific white shrimp, Litopenaeus vannamei. Aquacult. Res. 43, 745-755. doi: 10.1111/j.1365-2109.2011.02883.x

Naylor, R. L., Hardy, R. W., Bureau, D. P., Chiu, A., Elliott, M., Farrell, A. P., et al. (2009). Feeding aquaculture in an era of finite resources. Proc. Natl. Acad. Sci. 106, 15103-15110. doi: 10.1073/pnas.0905235106

NRC (2011). Nutrient Requirements of Fish. Washington, DC: National Academy Press.

Parvez, S., and Raisuddin, S. (2005). Protein carbonyls: novel biomarkers of exposure to oxidative stress-inducing pesticides in freshwater fish Channa punctata (Bloch). Environ. Toxicol. Phar. 20, 112-117.

Roux, P. P., and Topisirovic, I. (2012). Regulation of mRNA translation by signaling pathways. Cold Spring Harb. Perspect. Biol. 4, 843-853. doi: 10.1128/ MCB.00070-18

Shen, J. F., Liu, H. Y., Tan, B. P., Dong, X. H., Yang, Q. H., Chi, S. Y., et al. (2020). Effects of replacement of fishmeal with cottonseed protein concentrate on the growth, intestinal microflora, haematological and antioxidant indices of juvenile golden pompano (Trachinotus ovatus). Aquacult. Nutr. 26, 1119-1130. doi: 10.1111/anu.13069

Song, F., Xu, D. D., Mai, K. S., Zhou, H. H., Xu, W., and He, G. (2016). Comparative study on the cellular and systemic nutrient sensing and intermediary metabolism after partial replacement of fishmeal by meat and bone meal in the diet of turbot (Scophthalmus maximus L.). PLoS One 11:e0165708. doi: 10.1371/journal.pone.0165708

Su, J. Z., Gong, Y. L., Mei, L. Y., Xi, L. W., Chi, S. Y., Yang, Y. X., et al. (2020). The characteristics of glucose homeostasis in grass carp and chinese longsnout catfish after oral starch administration: A comparative study between herbivorous and carnivorous species of fish. Br. J. Nutr. 123, 627-641. doi: $10.1017 /$ S0007114519003234

Tamura, S., and Shimomura, L. (2005). Contribution of adipose tissue and de novo lipogenesis to nonalcoholic fatty liver disease. J. Clin. Invest. 115, 1139-1142. doi: 10.1172/JCI24930

Tu, Y. Q., Xie, S. Q., Han, D., Yang, Y. X., Jin, J. Y., and Zhu, X. M. (2015). Dietary arginine requirement for gibel carp (Carassis auratus gibelio var. CAS III) reduces with fish size from $50 \mathrm{~g}$ to $150 \mathrm{~g}$ associated with modulation of genes involved in TOR signaling pathway. Aquaculture 449, 37-47. doi: 10.1016/j. aquaculture.2015.02.031

Turchini, G. M., Trushenski, J. T., and Glencross, B. D. (2018). Thoughts for the Future of Aquaculture Nutrition: Realigning Perspectives to Reflect Contemporary Issues Related to Judicious Use of Marine Resources in Aquafeeds. N. Am. J. Aquacult. 81, 13-39. doi: 10.1002/naaq.10067

Wan, M. G., Yin, P., Fang, W. P., Xie, S. W., Chen, S. J., Tian, L. X., et al. (2018). The effect of replacement of fishmeal by concentrated dephenolization cottonseed protein on the growth, body composition, haemolymph indexes and haematological enzyme activities of the pacific white shrimp (Litopenaeus vannamei). Aquacult. Nutr. 24, 1845-1854. doi: 10.1111/anu.12823

Wang, J., Tao, Q. Y., Wang, Z., Mai, K. S., Xu, W., Zhang, Y. J., et al. (2016). Effects of fish meal replacement by soybean meal with supplementation of functional compound additives on intestinal morphology and microbiome of
Japanese seabass (Lateolabrax japonicus). Aquacult. Res. 48, 2186-2197. doi: 10.1111/are.13055

Wang, L., Cui, Z. H., Ren, X., Li, P., and Wang, Y. (2021). Growth performance, feed cost and environmental impact of largemouth bass Micropterus salmoides fed low fish meal diets. Aquacult. Rep. 20:100757. doi: 10.1016/j.aqrep.2021. 100757

Yaghoubi, M., Torfi, M. M., Ghafle, M. J., Safari, O., Hekmatpour, F., and Gisbert, E. (2020). Lysine and methionine supplementation in high soy protein content diets for silvery-black porgy (Sparidentex hasta) juveniles. Iran. J. Fish. Sci. 19, 1329-1343. doi: 10.22092/IJFS.2019.119235

Yang, B. Y., Zhai, G., Gong, Y. L., Han, D., Yin, Z., Xie, S. Q., et al. (2018). Different physiological roles of insulin receptors in mediating nutrient metabolism in zebrafish. Am. J. Physiol.: Endocrinol. Metab. 315, E38-E51. doi: 10.1152/ ajpendo.00227.2017

Ye, H. Q., Xu, M. L., Chen, L. L., Tan, X. H., and Wang, A. L. (2019). Effects of dietary plant protein sources influencing hepatic lipid metabolism and hepatocyte apoptosis in hybrid grouper (Epinephelus lanceolatus $\$ \times$ Epinephelus fuscoguttatuso'). Aquaculture 506, 437-444. doi: 10.1016/j. aquaculture.2019.03.075

Yin, B., Liu, H. Y., Tan, B. P., Dong, X. H., Chi, S. Y., Yang, Q. H., et al. (2018). Cottonseed protein concentrate (CPC) suppresses immune function in different intestinal segments of hybrid grouper oEpinephelus fuscoguttatus $\times \sigma^{7}$ Epinephelus lanceolatu via TLR-2/Myd 88 signaling pathways. Fish. Shellfish Immunol. 81, 318-328. doi: 10.1016/j.fsi.2018.07.038

Yu, H. H., Zhang, L. L., Chen, P., Liang, X. F., Cao, A. Z., Han, J., et al. (2019). Dietary bile acids enhance growth, and alleviate hepatic fibrosis induced by a high starch diet via AKT/FOXO1 and cAMP/AMPK/SREBP1 pathway in Micropterus salmoides. Front. Physiol. 10:1430-1430.

Yuan, X. Y., Jiang, G. Z., Cheng, H. H., Cao, X. F., Shi, H. J., and Liu, W. B. (2019). An evaluation of replacing fish meal with cottonseed meal protein hydrolysate in diet for juvenile blunt snout bream (Megalobrama amblycephala): growth, antioxidant, innate immunity and disease resistance. Aquacult. Nutr. 25, 13341344. doi: 10.1111/anu.12954

Zhang, Y., Chen, P., Liang, X. F., Han, J., Wu, X. F., Yang, Y. H., et al. (2019). Metabolic disorder induces fatty liver in japanese seabass, Lateolabrax japonicas fed a full plant protein diet and regulated by cAMP-JNK/NF-kB-caspase signal pathway. Fish Shellfish Immunol. 90, 223-234. doi: 10.1016/j.fsi.2019.04.060

Zhang, Y., Xie, S., Wei, H., Zheng, L., Liu, Z., Fang, H., et al. (2020). High dietary starch impaired growth performance, liver histology and hepatic glucose metabolism of juvenile largemouth bass, Micropterus salmoides. Aquacult. Nutr. 26, 1083-1095. doi: 10.1111/anu.13066

Zhao, W., Liu, Z. L., and Niu, J. (2021). Growth performance, intestinal histomorphology, body composition, hematological and antioxidant parameters of Oncorhynchus mykiss were not detrimentally affected by replacement of fish meal with concentrated dephenolization cottonseed protein. Aquacult. Rep. 19:100557. doi: 10.1016/j.aqrep.2020.100557

Zhou, Q. L., Habte-Tsion, H. M., Ge, X., Xie, J., Ren, M., Liu, B., et al. (2018). Graded replacing fishmeal with canola meal in diets affects growth and target of rapamycin pathway gene expression of juvenile blunt snout bream, Megalobrama amblycephala. Aquacult. Nutr. 24, 300-309. doi: 10.1111/anu. 12560

Conflict of Interest: The authors declare that the research was conducted in the absence of any commercial or financial relationships that could be construed as a potential conflict of interest.

Publisher's Note: All claims expressed in this article are solely those of the authors and do not necessarily represent those of their affiliated organizations, or those of the publisher, the editors and the reviewers. Any product that may be evaluated in this article, or claim that may be made by its manufacturer, is not guaranteed or endorsed by the publisher.

Copyright (c) $2021 \mathrm{Liu}, \mathrm{Lu}, \mathrm{Xi}$, Gong, Su, Han, Zhang, Liu, Jin, Yang, Zhu and Xie. This is an open-access article distributed under the terms of the Creative Commons Attribution License (CC BY). The use, distribution or reproduction in other forums is permitted, provided the original author(s) and the copyright owner(s) are credited and that the original publication in this journal is cited, in accordance with accepted academic practice. No use, distribution or reproduction is permitted which does not comply with these terms. 